\title{
Influence of agricultural land-use and pesticides on benthic macroinvertebrate assemblages in an agricultural river basin in southeast Brazil
}

\author{
Egler, M. ${ }^{a}$, Buss, DF. ${ }^{a}$, Moreira, JC. ${ }^{b}$ and Baptista, DF. ${ }^{a *}$ \\ a'Laboratório de Avaliação e Promoção da Saúde Ambiental - LAPSA, Instituto Oswaldo Cruz - IOC, \\ Fundação Oswaldo Cruz - FIOCRUZ, Av. Brasil, 4365, Manguinhos, CEP 21040-360, Rio de Janeiro, RJ, Brazil

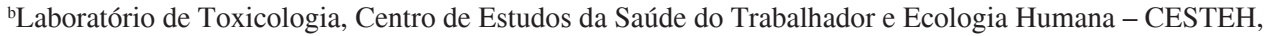 \\ Escola Nacional de Saúde Pública Sergio Arouca - ENSP, Fundação Oswaldo Cruz - FIOCRUZ, Av. Brasil, 4365, \\ Manguinhos, CEP 21040-360, Rio de Janeiro, RJ, Brazil \\ *e-mail:darcilio@ioc.fiocruz.br
}

Received June 7, 2011 - Accepted September 16, 2011 - Distributed August 31, 2012

(With 3 figures)

\begin{abstract}
Land-use alterations and pesticide run-offs are among the main causes for impairment in agricultural areas. We evaluated the influence of different land-uses (forest, pasture and intensive agriculture) on the water quality and on benthic macroinvertebrate assemblages on three occasions: in the dry season, wet season and at the end of the wet season. Macroinvertebrates responded to this gradient of impairment: agricultural sites had significantly lower richness numbers than forested and pasture sites, and all major invertebrate groups were significantly affected. Most taxa found in forested sites were found in pasture sites, but often with lower densities. In this case, the loss of habitats due to sedimentation and the lower complexity of substrates seem to be the disruptive force for the macroinvertebrate fauna.
\end{abstract}

Keywords: stream ecosystems, water quality, macroinvertebrates, biomonitoring, agricultural river basins.

\section{Influência de pesticidas e uso da terra sobre as assembléias de macroinvertebrados bentônicos em uma bacia hidrográfica no Sudeste do Brasil}

\begin{abstract}
Resumo
O desmatamento e o uso de pesticidas representam impactos importantes que ameaçam a integridade ambiental das áreas agrícolas. Neste estudo, foi avaliada a influência de diferentes usos do solo associados com atividades agrícolas (floresta, pastagem e agricultura intensiva) na qualidade da água e em comunidades de macroinvertebrados bentônicos em três ocasiões: estação seca, estação chuvosa e fim da estação chuvosa. A comunidade de macroinvertebrados bentônicos respondeu a esse gradiente de impacto: as áreas intensamente ocupadas por cultivos apresentaram uma riqueza significativamente menor do que as áreas florestadas e ocupadas por pastagens, com todos os grupos de macroinvertebrados sendo significativamente afetados. A maior parte dos táxons encontrados nas áreas de floresta foi registrada nas áreas de pastagem, mas sempre em menores densidades. Nesse caso, a redução de habitat em função da sedimentação e da menor heterogeneidade de substratos parece ser o principal impacto que ameaça a comunidade.
\end{abstract}

Palavras-chave: ecossistemas de rios, qualidade da água, macroinvertebrados aquáticos, biomonitoramento, áreas agrícolas.

\section{Introduction}

Impacts of agricultural activities on freshwater ecosystems are well documented worldwide and include changes in riparian vegetation and stream morphology, increased erosion and siltation, nutrient and organic enrichment and pesticide contamination (Hawkins et al., 1982; Cooper, 1991; Watzin and MacIntosh, 1999; Lair and Valadas, 2000; Whiles et al., 2000; Neumann and Dudgeon, 2002; Bahar et al., 2008).

In the southeastern region of Brazil, agriculture is fundamental to feed 78 million inhabitants - of which more than $90 \%$ live in urban areas (IBGE, 2007). As a result of poor management practices, studies have shown detectable levels of pesticide contamination in water samples (Alves, 2000; Filizola et al., 2002; Müller et al., 2002), due to the low educational level of rural workers 
and absence of adequate supervising or technical advice (Moreira et al., 2002).

Evaluation of pesticide contamination in freshwaters is not easy - contamination events are generally diffuse and episodic in nature (Watzin and MacIntosh, 1999; Neumann and Dudgeon, 2002; Friberg et al., 2003). Concentration of pesticides in water is usually low, since most formulations are soluble in water and are affected by dilution (Wauchope, 1978). Also, chemical inputs in streams and rivers may occur in pulses following rainfall events and soon after pesticide applications (Gruessner and Watzin, 1996).

Biological monitoring is an alternative approach in cases of sporadic and non-point sources of pollution (Buikema and Voshell, 1993; Rosenberg and Resh, 1993). Different human activities can alter physical, chemical or biological processes associated with water resources and thus modify the resident biological assemblages (EC - European Commission, 2000). Changes in species richness and abundance can be a signal of impairment and, together with other traditional measures, may be used to register environmental degradation (Rosenberg and Resh, 1993). The advantages of using biological indicators include long term assessments and higher sensitivity to detect subtle changes in water quality and low concentrations of chemicals. Also, biological responses tend to integrate the independent and interactive effects of many stressors, resulting in more robust indicators than analysis of individual chemicals (Cairns and Pratt, 1993; Cairns et al.,1993).

In the last 20 years, great efforts are being made to establish bioassessment protocols in Brazil using benthic macroinvertebrates (Baptista et al., 2007; Buss and Borges 2008; Mugnai et al., 2008; Moreno et al., 2009; Buss and Vitorino 2010; Ferreira et al., 2011). In order to develop more effective biomonitoring tools, ecological processes and biological responses must be analysed carefully. This study aimed to evaluate the influence of modifications in land-use and the use of pesticides on benthic macroinvertebrate assemblages in two agricultural river basins in southeast Brazil. Also, we were interested in finding which variables influenced macroinvertebrate assemblages the most.

\section{Methods}

\subsection{Study area}

The study was carried out in a mountainous area in Rio de Janeiro state, southeast Brazil. This region, known as Serra do Mar, is characterised by medium altitude valleys (600-1200 m.a.s.l.), and occupied mainly by rural properties, medium-sized cities and few forest remnants. This area is the greatest producer of olericultural plants (kitchen herbs) in the state. Deforestation of riparian vegetation in headwater areas and water contamination by pesticides and fertilizers are the major threats to freshwater resources. Two river basins located in the same ecoregion were used in this study: the São Lourenço River and the Varginha River basin. The São Lourenço River drains an area intensively used for production of kitchen herbs. Due to climate and rotation of cultures, production is continuous all over the year in this region, with a wide array of pesticides being used, (organophosphorous, carbamates, pyrethroids and bipyridil herbicides) (Moreira et al., 2002). The Varginha River valley is geographically similar, but used mainly for cattle ranching. The headwaters region is well preserved and there are no noticeable agricultural cultivations. However, human pressure is increasing in this region and there are deforested areas along the river.

Six stream reaches were used for biological, chemical, physical and environmental assessments. One forested and one pasture site were sampled for each basin (S1 and S2 in the São Lourenço River; V1 and V2 in the Varginha River), and two other sites draining cultivated areas were sampled for the São Lourenço River (S3 and S4). Sites S1 and V1 were at well-preserved forested areas, with riparian vegetation closely associated with the stream, and streambed dominated by boulders and coarse sediment. Site $\mathrm{S} 2$ was around 300 metres downstream from the border of the forested area, and although it had no local riparian vegetation, the site showed stable margins and the stream bed was dominated by cobbles, gravel and litter from the upstream forested area. No clear agricultural or cattle activities were observed in this area. In site V2 pasture was also predominant - also with no proximity of cattle production - and the site had finer sediments, few natural retention mechanisms, and the streambed was dominated entirely by sand. The other two sites were located in cultivated areas (sites S3 and S4), where the stream was channeled with steep margins and the streambed was dominated by sand and silt. At these two sites, few stable substrates were available and where rocks were found they were covered with aquatic macrophytes (Figure 1). These two sites were chosen based on Alves (2000) and Moreira et al. (2002) which found concentrations of organophosphorous pesticides in stream water samples at both sites $(76.80 \pm 10.89 \mathrm{mg} / \mathrm{L}$ at $\mathrm{S} 3$ and $37.16 \pm 6.39 \mathrm{mg} / \mathrm{L}$ at $\mathrm{S} 4)$.

\subsection{Analytical methods}

A Surber sampler (mesh size $125 \mu \mathrm{m}, 900 \mathrm{~cm}^{2}$ area) was used to collect the macroinvertebrate fauna. Three replicates of each of the four microhabitats (sediment, stones, litter in pool areas and litter in riffle areas) were sampled. Samplings were performed in three occasions, determined by rain regime and seasonality of crops production: dry season (August 2000), wet season (February 2001) and end of the wet season (May 2001). Biological samples were preserved in the field with $80 \%$ ethanol and packed for further examination. In the laboratory all biological samples were examined under a stereoscopic microscope. Macroinvertebrates were sorted, counted and identified mostly at genus level using available taxonomic keys (Ephemeroptera-DaSilva et al., 2003; Salles et al., 2004; Odonata - Carvalho, 1989; Carvalho and Calil, 2000; Carvalho et al., 2002; Plecoptera - Olifiers et al., 2004; Hemiptera - Nieser and De Mello, 1997; Trichoptera - Angrisano, 1995; Wiggins, 1996; other groups - Merritt and Cummins, 1996). 


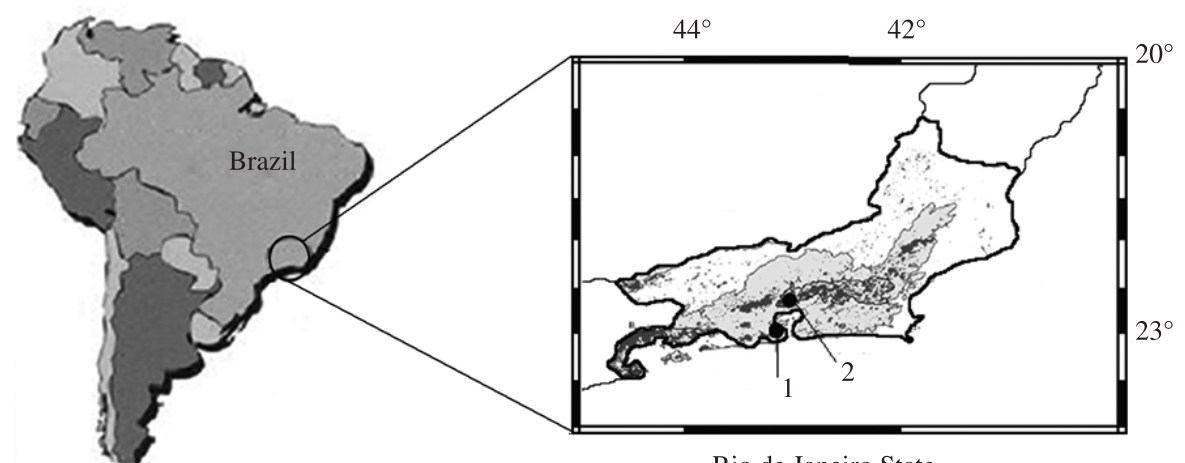

Rio de Janeiro State
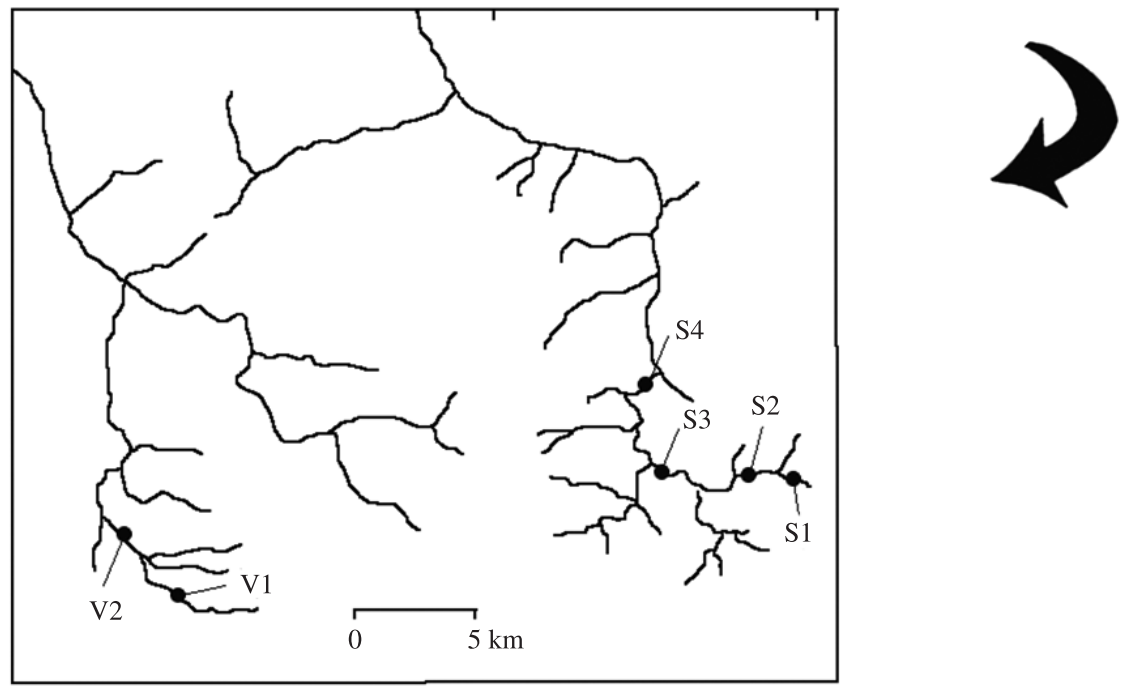

Figure 1. Map of Rio de Janeiro state, Brazil. Light grey areas indicate original limits of the Atlantic rainforest and dark grey areas indicate forest remnants. 1- Rio de Janeiro city; 2 - study area - box indicates approximate limits of the sampling sites in watershades (V1 and V2 -Varginha basin and S1, S2, S3, S4, São Lourenço Basin).

Several physical and chemical measures were recorded in the field each time a biological sample was taken: $\mathrm{pH}$, dissolved oxygen, water and air temperature, mean water depth, river width and current velocity (using the flotation method). Also, a water sample was taken and frozen for further laboratory analysis following FEEMA (1979) procedures: alkalinity, hardness, $\mathrm{Cl}-, \mathrm{NH} 3-\mathrm{N}, \mathrm{NO}_{3}-\mathrm{N}, \mathrm{PO}_{4}-\mathrm{P}$, total and fecal coliforms and pesticides. Pesticide analyses were specific for anticholinesterasic agents and were performed using the enzymatic method. In this method, a rat brain acetylcholinesterase preparation is used to detect pesticide concentrations (Cunha Bastos et al.,1991; Lima et al., 1996). The results are expressed in methyl-parathion equivalents and the detection limit is of $5 \mu \mathrm{g} / \mathrm{L}$.

An environmental assessment of each site was performed at each sampling period, using the Riparian Channel Environment index (RCE; Petersen, 1992). The RCE index is calculated based on sixteen environmental parameters such as land-use patterns, stream channel morphology and riparian vegetation. For each parameter a score is given, summed, and the final score is compared to a table to determine one of the five classes of environmental integrity.

Analysis of variance (ANOVA) was used to evaluate the influence of the different land-uses on the physical and chemical parameters of the water, and richness and abundance of macroinvertebrates.

\section{Results}

Forested and pasture sites had similar physical, chemical and bacteriological analyses ( $p>0.05$ for all pairs of data). The only significant difference between these land-uses was the RCE-score $\left(\mathrm{F}_{1,10}=69.07 ; \mathrm{p}<0.0001\right)$ (Table 1). Sites with agricultural activities had significantly higher values of NH3-N than forested and pasture sites $\left(\mathrm{F}_{1,10}=28.09\right.$; $\mathrm{p}<0.001 ; \mathrm{F}_{1,10}=28.91 ; \mathrm{p}<0.001$, respectively), $\mathrm{NO}_{3}-\mathrm{N}$ $\left(\mathrm{F}_{1,10}=30.51 ; \mathrm{p}<0.001 ; \mathrm{F}_{1,10}=29.79 ; \mathrm{p}<0.001\right), \mathrm{PO}_{4}-\mathrm{P}$ $\left(\mathrm{F}_{1,10}=5.56 ; \mathrm{p}<0.05 ; \mathrm{F}_{1,10}=4.89 ; \mathrm{p}<0.05\right)$, Thermotolerant Coliforms $\left(\mathrm{F}_{1,10}=11.27 ; \mathrm{p}<0.01 ; \mathrm{F}_{1,10}=6.65 ; \mathrm{p}<0.05\right)$, and Hardness $\left(\mathrm{F}_{1,10}=20.62 ; \mathrm{p}<0.01 ; \mathrm{F}_{1,10}=13.85 ; \mathrm{p}<0.01\right)$. Also, these sites had lower RCE-scores $\left(\mathrm{F}_{1,10}=463.00\right.$; 
$\left.\mathrm{p}<0.0001 ; \mathrm{F}_{1,10}=22.19 ; \mathrm{p}<0.0001\right)($ Table 1). Enzymatic essays detected pesticides in samples from agricultural sites: both sites were positive for methyl parathion equivalents in the end of the wet season sampling period $(12.5 \mu \mathrm{g} / \mathrm{L}$ in $\mathrm{S} 3$ and $15.0 \mu \mathrm{g} / \mathrm{L}$ in $\mathrm{S} 4)$.

\subsection{Biological data}

A total of 131,485 specimens were collected, with 106 taxa belonging to 13 orders and 53 families. Richness numbers were significantly different between land-uses $\left(\mathrm{F}_{2,15}=58.32\right.$; $\mathrm{p}<0.0001)$. Forested and pasture sites had similar richness numbers $\left(\mathrm{F}_{1,10}=4.03 ; \mathrm{p}=0.07\right)$, but agricultural sites had significantly lower richness numbers than forested and pasture sites $\left(\mathrm{F}_{1,10}=49.63 ; \mathrm{p}<0.0001 ; \mathrm{F}_{1,10}=136.82\right.$; $\mathrm{p}<0.0001$, respectively). This pattern was consistent over the study, with agricultural sites always having the lowest richness numbers (Figure 2). All invertebrate groups were significantly affected. Richness of the insect orders Coleoptera and Hemiptera differed between the three land-uses, with

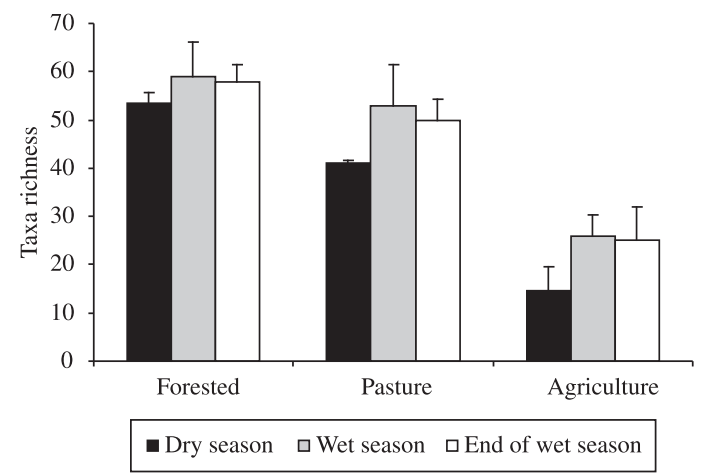

Figure 2. Taxa richness collected at sites with different land-uses during the dry season (dark bars), wet season (grey bars) and end of wet season (white bars) in the São Lourenço River Basin, Rio de Janeiro state. reducing numbers in the forested-pasture-agricultural gradient (both $\mathrm{p}<0.001$ ). Diptera, Odonata, Ephemeroptera, Plecoptera and Trichoptera had similar richness numbers between forested and pasture sites (all $\mathrm{p}>0.05$ ), but both land-uses were significantly different than agricultural sites (p-levels $=0.02$ to $<0.001$ ) (Figure 3). Notably, Plecoptera, Leptophlebiidae (Ephemeroptera) and four families of Trichoptera (Calamoceratidae, Helicopsychidae, Hydrobiosidae and Odontoceridae) were not found in any agricultural site. The whole order Odonata was absent in site S4 (Table 2). In the pasture site, three taxa occurred predominantly: one Diptera (Psychodidae 86\% in pasture sites, $\mathrm{n}=718$ ), and two Trichoptera (Marilia, Odontoceridae 74\%, n = 406; and Atopsyche, Hydrobiosidae $63 \%, \mathrm{n}=236$ ). In the agricultural sites, predominant taxa were two Ephemeroptera, (Baetidae: Americabaetis $63 \%, \mathrm{n}=3101$; and Camelobaetidius 93\%, $\mathrm{n}=266$ ), two Trichoptera (Protoptila, Glossosomatidae 88\%, $\mathrm{n}=50$; and

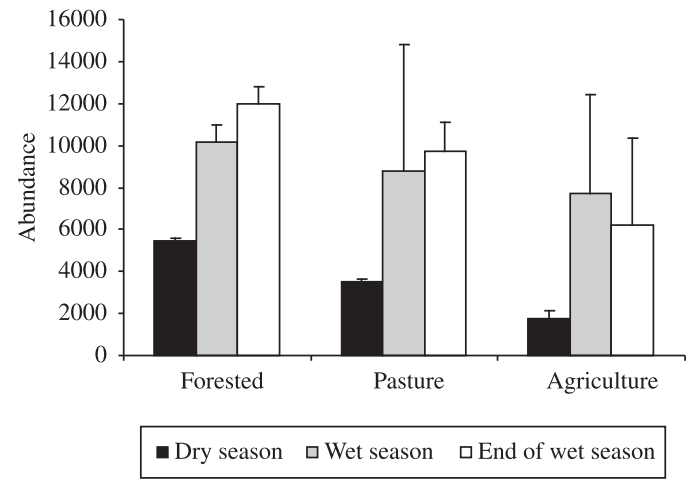

Figure 3. Number of individuals collected at sites with different land-uses during the dry season (dark bars), wet season (grey bars) and end of wet season (white bars) in the São Lourenço River Basin, Rio de Janeiro state.

Table 1. Mean values (SD) of environmental, physical-chemical and bacteriological analyses collected at sites with different land uses in São Lourenço and Varginha basin, Rio de Janeiro state. For each variable, values with the same superscript were not significantly different ( $\mathrm{n}$ sites/occasions $=6$ ).

\begin{tabular}{lccc}
\hline & Forested sites & Pasture sites & Agricultural sites \\
\hline $\mathrm{pH}$ & $7.18(0.22)$ & $6.80(0.18)$ & $7.13(0.24)$ \\
Alkalinity $\left(\mathrm{mg} . \mathrm{L}^{-1}\right)$ & $10.00(2.23)$ & $9.09(1.15)$ & $11.20(1.36)$ \\
Hardness $\left(\mathrm{mg} . \mathrm{L}^{-1}\right)$ & $11.00(1.10)$ & $12.67(1.63)$ & $21.33(5.47)$ \\
Dissolved Oxygen $\left(\mathrm{mg} . \mathrm{L}^{-1}\right)$ & $8.58(0.88)$ & $8.23(0.76)$ & $7.98(0.67)$ \\
$\mathrm{Cl}^{-}\left(\mathrm{mg} . \mathrm{L}^{-1}\right)$ & $6.88(1.41)$ & $8.35(1.74)$ & $8.11(1.46)$ \\
$\mathrm{PO}_{4}-\mathrm{P}\left(\mathrm{mg} . \mathrm{L}^{-1}\right)$ & $0.01(0.01)$ & $0.03(0.02)$ & $0.16(0.15)$ \\
$\mathrm{NO}_{3}-\mathrm{N}\left(\mathrm{mg} . \mathrm{L}^{-1}\right)$ & $0.06(0.06)$ & $0.07(0.05)$ & $0.33(0.10)$ \\
$\mathrm{NH}_{3}-\mathrm{N}\left(\mathrm{mg} . \mathrm{L}^{-1}\right)$ & $0.09(0.09)$ & $0.09(0.09)$ & $0.71(0.27)$ \\
Total Coliforms $(\mathrm{MPN} / 100 \mathrm{~mL})$ & $1,101(1,065)$ & $2,133(1,525)$ & $5,633(5,875)$ \\
Termotolerant Coliforms$(\mathrm{MPN} / 100 \mathrm{~mL})$ & $53.33(75.01)$ & $147.33(219.97)$ & $666.67(441.21)$ \\
Methyl-parathion equivalents $\left(\mu \mathrm{g} . \mathrm{L}^{-1}\right)$ & 0 & 0 & $4.58(7.14)$ \\
RCE & $290.83(8.61)$ & $130.17(46.56)$ & $40.50(2.51)^{\mathrm{c}}$ \\
Altitude (m a.s.l.) & 1,100 & 1,000 & 900 \\
\hline
\end{tabular}


Table 2. Taxa richness for benthic macroinvertebrates from streams in forested (S1 and V1), pasture (S2 and V2) and agricultural areas (S3 and S4).

\begin{tabular}{|c|c|c|c|c|c|c|}
\hline & \multicolumn{2}{|c|}{ Forested } & \multicolumn{2}{|c|}{ Pasture } & \multicolumn{2}{|c|}{ Agricultural } \\
\hline & S1 & V1 & S2 & V2 & S3 & S4 \\
\hline Coleoptera richness & 22 & 22 & 23 & 22 & 15 & 14 \\
\hline Diptera richness & 10 & 9 & 10 & 9 & 8 & 7 \\
\hline Ephemeroptera richness & 11 & 16 & 13 & 14 & 7 & 8 \\
\hline Hemiptera richness & 6 & 7 & 7 & 7 & 2 & 2 \\
\hline Lepidoptera richness & 1 & 1 & 1 & 1 & 1 & 1 \\
\hline Megaloptera richness & 1 & 1 & 1 & 0 & 0 & 0 \\
\hline Odonata richness & 5 & 9 & 7 & 7 & 4 & 0 \\
\hline Plecoptera richness & 5 & 5 & 5 & 3 & 0 & 0 \\
\hline Trichoptera richness & 17 & 17 & 17 & 14 & 10 & 10 \\
\hline Non-insect richness & 5 & 6 & 6 & 4 & 5 & 4 \\
\hline Total richness & 83 & 92 & 89 & 80 & 51 & 45 \\
\hline Number of individuals & 27,567 & 28,147 & 32,027 & 12,368 & 17,084 & 14,292 \\
\hline Evenness (J) & 0.384 & 0.658 & 0.346 & 0.442 & 0.401 & 0.450 \\
\hline Diversity (H') & 1.69 & 2.97 & 1.55 & 1.93 & 1.57 & 1.7 \\
\hline
\end{tabular}

Nectopsyche, Leptoceridae $89 \%, \mathrm{n}=5270)$, Oligochaeta $(69 \%, \mathrm{n}=1930)$, and Collembola $(86 \%, \mathrm{n}=52)$.

Both basins had similar faunal composition (84 taxa in $\mathrm{S} 1-\mathrm{S} 2$ sites, 83 taxa in V1-V2 sites, with 73 taxa in common). However, the Varginha river basin had a higher equitability and predominance of more sensitive taxa (sites V1 - V2 presented 39,884 individuals with higher abundance of Paragripopteryx, Anacroneuria, Phylloicus, Helicopsyche, Grumichela and Marilia, Equitability $\mathrm{J}=0.61$, and sites S1 - S2 presented 59,339 individuals with higher abundance of Chironomidae, Simuliidae, Americabaetis and Baetodes, Equitability $\mathrm{J}=0.36$ )

\section{Discussion}

Water chemical analysis indicated little difference between forested and pastures sites, and significant differences between them and agricultural sites. Major differences were related to nutrient enrichment $\left(\mathrm{PO}_{4}-\mathrm{P}, \mathrm{NO}_{3}-\mathrm{N}, \mathrm{NH}_{3}-\mathrm{N}\right)$ and the presence of anticholinesterasic pesticides. Increase in coliform numbers also suggest that animal manure (mostly from loosely confined cattle) and/or domestic sewage may also be influencing ecological conditions. Biological data followed this environmental-chemical gradient. Most taxa found in forested sites were present in pasture sites, but with lower densities (especially for V2). Impacts in agricultural sites were evident. Intensely-deforested river basins often show drastic changes in their river morphology. In the study area, signs of riverside erosion are evident. In such conditions, there are increased inputs of sediments in the stream, and the available substrates become more unstable, less complex and with less coarse organic particulate matter for the fauna (Schulz, 2001; Rios and Bailey, 2006). As a consequence, in-stream refuges for the biota progressively disappear (Dudgen, 2000; Maul et al., 2004). Therefore, the loss of habitats due to sedimentation and/or the lower complexity of substrates may be one of the most disruptive forces for the macroinvertebrate fauna in this region (Buss et al., 2004).This impact affected both sites impacted by pastures and by agriculture. On the other hand, agricultural impacts together with pesticide runoff resulted in the reduction of taxa richness (sites S3 e S4). Other studies corroborate our findings of agricultural sites having lower taxa richness (Lenat, 1984) and less sensitive groups, resulting in a more dominant community structure (Lenat and Crawford, 1994; Hepp et al., 2010).

Despite the overall reduction in abundance and richness with increased impairment, some taxa increased their abundance in agricultural sites: Camelobaetidius (Baetidae; 93\% of the 268 individuals) and Protoptila (Glossossomatidae; $84 \%$ of 50 individuals). Both taxa are scrapers (see Baptista et al., 2006 for Camelobaetidius). Strong linkages between macroinvertebrate herbivores and algal density and higher levels of nutrients have been suggested elsewhere (Justus et al. 2010). However, there are no records in the literature if these taxa are tolerant to such impairments or have a higher resistance to the pesticides used locally. We observed only in these sites all rocks covered by a thick mat of algae. Such growth is possibly influenced by the run-off of fertilizers, which is corroborated by the higher values of $\mathrm{N}$ and $\mathrm{P}$ found in these sites. Elevated nitrogen and phosphorous concentrations are a leading cause of water quality impairment and agriculture is a major source of nutrients (Black et al., 2010). In the São Lourenço basin cultivated areas are larger than in the Varginha basin. Also, along the longitudinal gradient there is less and narrower riparian buffer zones, so the river is more exposed to pesticide sprays, which may be determinant to reduce macroinvertebrate diversity (Maltby and Hills, 2008; Vischetti et al., 2008). 
Our results indicate that macroinvertebrate fauna responded well to the low-level of nutrient enrichment, and also to other impairments caused by agriculture and pasture such as physical habitat alterations. Further information is needed to establish metrics for a biological index to assess ecological condition of streams.

Acknowledgements - We thank CNPq PAPES V (403496/2008-0), CNPq/PROEP (400107/2011-2) and FIOCRUZ for the financial support for this study and also Valdiney Valin for water analysis.

\section{References}

ALVES, SR., 2000. Avaliação dos resíduos de pesticidas organofosforados e carbamatos por metodologia enzimática no Córrego de São Lourenço, Nova Friburgo-RJ. Rio de Janeiro: Escola Nacional de Saúde Pública. Fundação Oswaldo Cruz. 61 p. Dissertação de Mestrado.

ANGRISANO, EB., 1995. InsectaTrichoptera. In LOPRETTO, EC. and TELL, G. (Eds.). Ecossistemas de Aguas Continentales: metodologias para suestudioVolume III. Ediciones Sur La Plata Argentina. p. 897-1401.

BAHAR, MM., OHMORI, H. and YAMAMURO, M., 2008. Relationship between river water quality and land use in a small river basin running through the urbanizing area of Central Japan. Limnology, vol. 9, p. 19-26.

BAPTISTA, DF., BUSS, DF., DIAS, LG., NESSIMIAN, JL., DA SILVA, ER., MORAES-NETO, AHA., CARVALHO, SN., OLIVEIRA, MA. and ANDRADE, LR., 2006. Functional feeding groups of Brazilian Ephemeroptera nymphs: ultrastructure of mouthparts. Annales de Limnologie, vol. 42, no. 2, p. 87-96.

BAPTISTA, DF., BUSS, DF., EGLER, M., GIOVANELLI, A., SILVEIRA, MP. and NESSIMIAN, J. L., 2007. A multimetric index based on benthic macroinvertebrates for evaluation of Atlantic Forest streams at Rio de Janeiro State, Brazil. Hydrobiologia, vol. 575 , p. 83-94.

BENTHIC, D., 2000. BENTHIC community structure and effect of rotenone piscicide on invertebrate drift and standing stocks in two Papua New Guinea streams. Archivfür Hydrobiologie, vol. 119, p. $35-53$

BLACK, R., MORAN, P. and FRANKFORTER, J. 2010. Response of algal metrics to nutrients and physical factors and identification of nutrient thresholds in agricultural streams. Environmental Monitoring and Assessment, vol. 175, no. 1, p. 397-417.

BUIKEMA, AI. and VOSHELL, JR., 1993. Toxicity studies using freshwater benthic macroinvertebrates. In ROSEMBERG, DM. and RESH, VH. (Eds.). Freshwater biomonitoring and benthic macroinvertebrates. New York: Chappman\& Hall. p. 344-398.

BUSS, DF., BAPTISTA, DF., NESSIMIAN, J. L. and EGLER, M., 2004. Substrate specificity, environmental degradation and disturbance structuring macroinvertebrate assemblages in neotropical streams. Hydrobiologia, vol. 518, p. 179-188.

BUSS, DF. and BORGES, EL., 2008. Application of Rapid Bioassessment Protocols (RBP) for Benthic Macroinvertebrates in Brazil: Comparison between Sampling Techniques and Mesh Sizes. Neotropical Entomology, vol. 37, no. 3, p. 288-295.

BUSS, DF. and VITORINO, AS., 2010. Rapid Bioassessment Protocols using benthic macroinvertebrates in Brazil: evaluation of taxonomic sufficiency. Journal of North American Benthological Society, vol. 29, no. 2, p. 562-571.

CAIRNS, J. and PRATT, JR., 1993. A history of biological monitoring using benthic macroinvertebrates. In ROSEMBERG, DM. and RESH, VH. (Eds.). Freshwater biomonitoring and benthic macroinvertebrates. New York: Chappman\& Hall. p. 10-26.

CAIRNS, J., McCORMICK, PV. and NIEDERLEHNER, BR., 1993. a proposed framework for developing indicators of ecosystem health. Hydrobiologia, vol. 263, p. 1-44.

CARVALHO, AL., 1989. Description of the larvae of NeuraeschnaCostalis (Burmeister), with notes on its biology, and a key to the genera of Brazilian Aeshnidae Larvae (Anisoptera). Odonatologica, vol. 18, no. 4, p. 325-332.

CARVALHO, AL. and CALIL, ER., 2000. Chaves de Identificação para as famílias de Odonata (Insecta) ocorrentes no Brasil, adultos e larvas. Papéis Avulsos de Zoologia do Museu de Zoologia da USP, vol. 41, no. 15 , p. 223-241.

CARVALHO, AL., WERNECK-DE-CARVALHO, P. and CALIL, ER., 2002. Description of the larvae of two species of DasythemisKarsch, with a key to the genera of Libellulidae occurring in the states of Rio de Janeiro and São Paulo, Brazil (Anisoptera). Odonatologica, vol. 31, no. 1, p. 23-33.

COOPER, K., 1991. Effects of Pesticides on Wildlife. In HAYES, WJ. and LAWS, ER. (Eds.). Handbook of Pesticide Toxicology 1. General principles. Academic Press. p. 463-496.

CUNHA BASTOS, VLF., CUNHA BASTOS LIMA, JF. and CASTRO FARIA, MV., 1991. Brain acethylcholinesterase as an "in vitro" detector of organophosphorus and carbamate insecticides in the water. Water Research, vol. 25, p. 835-840.

DA-SILVA, ER., SALLES, FF., NESSIMIAN, JL. and COELHO, LBN., 2003. A identificação das famílias de Ephemeroptera (Insecta) ocorrentes no Estado do Rio de Janeiro: Chave pictórica para as ninfas. Boletim do Museu Nacional de Zoologia, vol. 508, p. 1-6.

European Commission, 2000. Directive 2000/60/EC of the European Parliament and Council, establishing a framework for Community action in the field of water policy. Official Journal of European Parliament, no. 327, p. 1-72.

FERREIRA, WR., PAIVA, LT. and CALLISTO, M., 2011. Development of a benthic multimetric index for biomonitoring of a neotropical watershed. Brazilian Journal of Biology, vol. 71, no. 1, p. $15-25$.

FILIZOLA, H., FERRACINI, VL., SANS, LMA., GOMES, MAF. and FERREIRA, JA., 2002. Monitoramento e avaliação do risco de contaminação por pesticidas em água superficial e subterrânea na região de Guaíra. Revista de Pesquisa Agropecuária no Brasil, vol. 37 , no. 5, p. 659-667.

FRIBERG, N., LINDSTRØM, M., KRONVANG, B. and LARSEN, SE., 2003. Macroinvertebrate/sediment relationships along a pesticide gradient in Danish streams. Hydrobiologia, vol. 494, no. $1-3$, p. 103-110.

Fundação Estadual de Engenharia do Meio Ambiente - FEEMA, 1979. Métodos de análise físico-química da água. Rio de Janeiro: DICOMT. 3 vol. (Cadernos FEEMA, série didática, no. 14-79).

GRUESSNER, B. and WATZIN, MC., 1996. Response of a aquatic communities from a vermont stream environmentally realistic atrazine exposure in laboratory microcosms. Environmental Toxicology and Chemistry, vol. 15, no. 4, p. 410-419. 
HAWKINS, CP., MURPHY, ML. and ANDERSON, NH., 1982. Effects of Canopy, substrate composition, and gradient on the structure of macroinvertebrate communities in cascade range streams of Oregon. Ecology, vol. 62, p. 1840-1856.

HEPP, LU., MILESI, SV., BIASI, C. and RESTELLO, RM., 2010. Effects of agricultural and urban impacts on macroinvertebrates assemblages in streams (Rio Grande do Sul, Brazil). Zoologia, vol. 27, no. 1, p. 106-113.

Instituto Brasileiro de Geografia e Estatística - IBGE, 2007. Contagem e Estimativas da População 2007. Diário Oficial da República Federativa do Brasil, Brasília, DF, 05 out. 2007.

JUSTUS, BG., PETERSEN, JC., FEMMER, SR., DAVIS, JV. and WALLACE, JE., 2010. A comparison of algal, macroinvertebrate, and fish assemblage indices for assessing low-level nutrients enrichment in wadeable Ozark streams. Ecological Indicators, vol. 10, p. 627-638.

LAIR, N. and VALADAS, B., 2000. Impact of Agricultural practices on a small headwater stream: terrestrial and aquatic characteristics and self-purifying processes. Hydrobiologia, vol. 421, p. 129-139.

LENAT, DR., 1984. Agriculture and stream water quality: biological evaluation of erosion control practices. Environmental Management, vol. 8, p. 333-344.

LENAT, DR. and CRAWFORD, JK., 1994. Effects of land use on water quality and aquatic biota of three North Carolina Piedmont streams. Hydrobiologia, vol. 294, p. 185-199.

LIMA, JS., 1996. Methyl parathion activation by partially purified rat brain fraction. Toxicological Letters, vol. 87, p. 53-60.

MALTBY, L. and HILLS, L., 2008. Spray drift of pesticides and stream macroinvertebrates: Experimental evidence of impacts and effectiveness of mitigation measures. Environmental Pollution, vol. 156 , no. 3 , p. 1112-1120.

MAUL, JD., FARRIS, JL., MILAM, CD., COPERS, CM., TESTA, S. and FELDMAN, DL., 2004. The influence of stream habitat and water quality on macroinvertebratecommunities in degraded streams of northwest Mississippi. Hydrobiologia, vol. 518, p. 79-94.

MERRITT, RW. and CUMMINS, KW. (Eds.), 1996. An Introduction to the Aquatic insects of North America. 3rd ed. Dubuque: Kendall, Hunt Publishing. p. 862.

MOREIRA, JC., CASTRO FARIA, MV., JACOB, SC., LIMA, JS., ALVES, SR., OLIVEIRA-SILVA, JJ., SARCINELLI, PN., BAPTISTA, DF., EGLER, M., FARIA, M., ARAÚJO, AJ., KUBOTA, AH., SOARES, MO., MOURA, CM. and CURI, R., 2002. Avaliação integrada do impacto do uso de agrotóxicos sobre a saúde humana de uma comunidade agrícola de Nova Friburgo, RJ. Revista de Saúde Coletiva, vol. 7, no. 2, p. 299-311.

MORENO, P., FRANÇA, JS., FERREIRA, WR., PAZ, AD., MANTEIRO, MI. and CALLISTO, M., 2009. Use of the BEST model for biomonitoring water quality in neotropical basin. Hydrobiologia, vol. 630, p. 231-242.

MUGNAI, R., OLIVEIRA, RB. CARVALHO, LC. and BAPTISTA, DF., 2008. Adaptation of the ÍndiceBioticoEsteso (IBE) for water quality. Tropical Zoology, vol. 21, p. 57-74.
MÜLLER, K., BACH, M., HARTMANN, H., SPITELLER, M. and FREDE, H., 2002. Point- and Nonpoint-Source Pesticide Contamination in the Zwester Ohm Catchment, Germany. Journal of Environmental Quality, vol. 31, p. 309-318.

NIESER, N. and DE MELO, AL., 1997. Os heterópteros aquáticos de Minas Gerais: guia introdutório com chave de identificação para as espécies de Nepomorpha e Gerromorpha. Belo Horizonte: Editora UFMG. p. 180.

NEUMANN, M. and DUDGEON, D., 2002. The impact of agricultural runoff on stream benthos in Hong Kong, China. Water Research, vol. 36, no. 12, p. 3103-3109.

OLIFIERS, MH., DORVILLÉ, LFM., NESSIMIAN, JL. and HAMADA, N., 2004. A key to Brazilian genera of Plecoptera (Insecta) based on nymphs. Zootaxa, vol. 651, p. 1-15.

PETERSEN, RC., 1992. The RCE a Riparian and Channel Inventory for small streams in the agricultural landscape. Freshwater Biology, vol. 27, p. 295-306.

RIOS, SL. and BAILEY, RC., 2006. Relationship between riparian vegetation and stream benthic communities at three spatial scales. Hydrobiologia, vol. 55, p. 153-160.

ROSENBERG, DM. and RESH, VH. (Eds.), 1993. Freshwaterbiomonitoring and benthic macroinvertebrates. New York: Chappman\& Hall. p. 488.

SALLES, FF., DA-SILVA, ER., SERRÃO, JE. and FRANCISCHETTI, CN., 2004 Baetidae (Ephemeroptera) na Região Sudeste do Brasil Novos registros e chave para os gêneros no estágio ninfal. Neotropical Entomology, vol. 33, no. 5, p. 725-735.

SCHULZ, R., 2001. Rainfal-induced sediment and pesticide input from orchards into the Lourens rivers, Westerm Cape, South Africa importance of a single event. Water Resources, vol. 35, no. 8 , p. $1869-1887$.

VISCHETTI, C., CARDINALI, A., MONACI, E., NICELLI, M., FERRARI, F., TREVISAN, M. and CAPRI, E., 2008. Measures to reduce pesticide spray drift in a small aquatic ecosystem in vineyard estate. Science of Total Environment, vol. 389, p. 497-502.

WATZIN, MC. and MACINTOSH, WA., 1999. Aquatic ecosystems in agricultural landscapes A review of ecological indicators and achievable ecological outcomes. Journal of Soil and Water Conservation, vol. 4, p. 636-644.

WAUCHOPE, RD., 1978. The pesticide content of surface water draining from agricultural fields: a review. Journal of Environmental Quality, vol. 7, p. 459-472.

WHILES, MR., BROCK, BL., FRANZEN, AC. and DINSMORE, SC., 2000. Environmental Auditing Stream invertebrate communities, water quality and land use patterns in an agricultural drainage basin in northeastern Nebraska, USA. Environmental Management, vol. 26, p. 563-576.

WIGGINS, GB., 1996. Larvae of the North American Caddisfly Genera (Trichoptera). 2nd ed. Toronto: University of Toronto Press. 457 p. 
